\title{
Determinants of intention to engage in Sustainability Accounting \& Reporting (SAR): the perspective of professional accountants
}

Teddy Ossei Kwakye, Emerald Edem Welbeck, Godfred Matthew Yaw Owusu* and Fred Kwasi Anokye

\begin{abstract}
This study examines the perception of professional accountants and the intention to engage in Sustainability Accounting \& Reporting (SAR). By relying on the Theory of Planned Behaviour (TPB), the study investigates whether attitudes, subjective norms and perceived behavioural control have any impact on a firm's intention to engage in SAR. A survey method of research was adopted, and a set of questionnaires was developed (based on existing studies) and administered to professional accountants- the respondent group. A total of 86 professional accountants in Ghana voluntarily participated in the study. The partial least square-SEM (PLS-SEM) technique was used to analyse the data obtained. The results from the structural analysis demonstrate that only subjective norm and perceived behavioural control significantly influence a firm's intention to engage in SAR. By implication, the attitude of an accountant towards SAR does not affect the intention to engage in the practice and that the willingness to engage in SAR is primarily determined by resources availability and pressure from major stakeholders.
\end{abstract}

Keywords: Sustainability reporting, Theory of planned behaviour, Accountants, Structural equation modelling

\section{Introduction}

Sustainability accounting and reporting (SAR), ${ }^{1}$ has received significant research attention in the field of accounting within the last two decades (Lamberton 2005; Schaltegger et al. 2013). The concept of SAR has evolved out of the need to increase corporate accountability and transparency about the impact of corporate decisions on the environment and society as a whole (Ball et al. 2000; Adams and Whelan 2009). This according to Henri and Journeault (2010) is critical to the development of decision support systems for enhancing corporate sustainability management. The importance of engaging in a SAR is well emphasised in the literature. As argued by some studies (Özsözgün Çalişkan 2014; Schaltegger and Burritt 2010), engaging in SAR may lead to potential legitimacy gains for firms and other corporate benefits necessary for the long-term value creation of firms.

\footnotetext{
* Correspondence: gmowusu@gmail.com; gmyowusu@ug.edu.gh Department of Accounting, University of Ghana Business School, Legon-Accra, Ghana
}

Although, prior literature suggests the existence of divergent views on what constitutes SAR and its processes (Parker 2011; Bebbington and Gray 2001; Burritt and Schaltegger 2010), majority of the existing studies recognise the relevance of accountants' involvement in environmental and sustainability management (Zvezdov et al. 2010; Evans et al. 2011). This consensus in part is attributable to the professional accountants' role in the conduct and design of firms' reporting system, preparation and interpretation of timely information to management to make informed socio-environmental and economic decisions (Özsözgün Çalişkan 2014; Aras and Crowther 2009b).

Generally, SAR involves corporate reporting on environmental, social responsibility and economic performance of firms, conceptualised as the triple bottom line (TBL) reporting' (Asif et al. 2011; Herzig and Schaltegger 2011). SAR augments the current external corporate financial reports in benefitting wider external parties of economies and societies, which hitherto have mostly been beneficial to shareholders of companies (Özsözgün Çalişkan 2014). ${ }^{2}$ SAR practices, thus, encompass companies reporting on 
their performance regarding the environment, health, safety and social matters, in addition to the traditional financial performance over a period. ${ }^{3}$ For this reason, SAR is suggested as part of firms' external reporting system (Sisaye 2011a, 2011b; Gray, 2006), for which the practical design and implementation of such system is a fundamental role of the professional accountant (Aras and Crowther 2009a, 2009b). Accountants also play an integral role in the value creation process of firms by providing services related to the development of sustainable business strategies - with their risk and opportunities evaluation skills (EY 2011), and SAR and assurance - by providing measurement, accounting, reporting and assurance skills (Özsözgün Çalişkan 2014). Moreover, accountants are perceived to be knowledgeable about the financial and non-financial information, including SAR, relevant for managerial decision-making and performance management and control (Granlund and Malmi 2002; Scapens and Jazayeri 2003; Jack and Kholeif 2008).

These traditional roles performed by the accountant in organisations, coupled with their advisory role to top management and decision makers, have positioned them in a very strategic way to influence the establishment and implementation of an efficient SAR system in organisations (Pierce and O'Dea 2003). The need for professional accountants to be more engaged in providing sustainability information has become more pressing than before because of: the need to comply with emerging jurisdictional requirements of sustainable development for organisations; market demands for firm's greater awareness of sustainability; and increased social/media attention from social change that has influenced the society's perceptions on sustainability (Parker 2000, 2011; Ferreira et al. 2010; Schaltegger and Zvezdov 2013; Mistry et al. 2014). In response to these demands, there has been a renewed effort by the accounting profession to address sustainability issues within the general framework of reporting (Özsözgün Çalişkan 2014; Lusher 2012).

However, while the professional accountants' roles and involvement in conventional accounting and reporting process are extensively researched in existing literature, very few studies have examined the involvement of accountants in SAR (Schaltegger and Zvezdov 2013; Albelda 2011). The few existing studies on accountants' involvement in SAR suggest that accountants are not adequately if at all, involved in environmental and sustainability information management in organisations (Wilmshurst and Frost 2001; Carter et al. 2011; O’Dwyer and Owen 2007; O'Dwyer 2002). Although professional accountants are acknowledged to have positive attitudes towards the environment, their response to SAR has been "fairly lukewarm and superficial" (Gray et al. 1993, 10) and mostly unwilling to get involved in SAR (Wilmshurst and Frost 2001; O’Dwyer 2002).
As Wilmshurst and Frost (2001) assert, the seeming reluctance of accountants to engage in SAR may be a reflection of their limited understanding of their roles towards sustainable development, which may be a consequent of their perception of the practice. ${ }^{4}$ For instance, it has been argued that some accountants generally perceive SAR to be only a means of gaining corporate legitimacy (O'Dwyer 2002), and also a practice beyond their purview (Wilmshurst and Frost 2001). An understanding of the accountants' perceptions on SAR is therefore relevant in predicting the extent of their engagement in practice and that of their companies. Moreover, the attitudes and perceptions of corporate managers and decision makers have also been found to significantly impact information disclosure, including SAR (Adams and McNicholas 2007; Wilmshurst and Frost 2001; Thoradeniya et al. 2015; O'Dwyer 2002). Suggestively, accountants' perception about SAR may affect their attitude towards SAR and their willingness to engage in the practice.

As studies on SAR increases and firms continue to embrace sustainability issues in both developed and developing countries (Schaltegger et al. 2013; Parker 2011; KPMG 2011), it is envisaged that most companies have gained better understanding and experience in SAR and its related issues (Bennett et al. 2013). However, SAR is still in its embryonic stage in developing countries in practice compared to developed countries (Belal and Owen 2007; KPMG 2011). Similarly, research focus on SAR in developing countries is still at the evolution stage compared with the developed world (Thoradeniya et al. 2015). The few existing studies from the perspective of developing countries have also concentrated in the Asia-Pacific region (Kamla et al. 2012; O'Dwyer et al. 2005; Belal and Owen 2007; Thoradeniya et al. 2015; Kuasirikun 2005). Moreover, despite the growing interest in SAR globally, questions still linger around whether accountants now understand their roles in SAR and most importantly their willingness to engage in the practice (Schaltegger and Zvezdov 2013). Besides, Gray et al. (2010, 36) call for studies to "discover why individuals [i.e. key managers, such as accountants] do (or do not) support and develop social accounting."

Guided by the fact that the perception and attitude towards SAR may be influenced by context-specific factors (Kamla et al. 2012), this study attempts to explore the perception of accountants towards SAR from Sub-Saharan African perspective. By relying on the Theory of Planned Behaviour (TPB), the study further investigates the factors that influence accountants' intentions to engage in SAR practices in Ghana. Our empirical analysis provides some relevant insights into the fundamental factors that can affect SAR practices in Ghana. Further, the current study adds-on to research on individuals' beliefs and perceptions 
about action and the effect on their attitude towards that action.

The next section of this paper reviews the current literature on SAR and highlights the need to examine the perceptions, intentions, and behaviour of professional accountants on SAR practices. The research design, data collection and the data analysis procedures employed are then described followed by the presentation of results and discussion of the findings. Lastly, some concluding remarks are given, and the implications of the findings are highlighted.

\section{Literature review}

Sustainability management which entails the formulation, implementation, and evaluation of the decisions and actions related to environmental, social and economic sustainability issues (Starik and Kanashiro 2013) has been an issue of interest to global businesses, researchers, and society at large. At the firm level, a key concern has been how corporate managers can minimise the impact of their firm's operations on the environment by establishing business systems, models and behaviours necessary for the long-term value creation of firms and sustainable development. Firms need to communicate all information on their management and performance on environmental, social, economic and sustainability issues to stakeholders by engaging in SAR to demonstrate their commitment to sustainable development. Consequently, the need for SAR practices by companies has been emphasised in the literature (Schaltegger et al. 2003; Martin and Hadley 2008) and within the last two decades, it has become an important concept in financial reporting that is receiving a significant amount of attention across the globe (KPMG 2011).

Despite the growing interest, it is apparent from existing literature that SAR is inadequately conceptualised as scholars are yet to have a consensus on the descriptive constituents, processes and expectations of SAR (Parker 2011; Bebbington and Gray 2001; Burritt and Schaltegger 2010). Nonetheless, SAR is widely construed to be concerned with the process through which organisations report to stakeholders on the social, environmental and economic impacts of their business activities (Asif et al. 2011; Herzig and Schaltegger 2011; Sisaye 2011a, 2011b). This process involves integrating the concerns for social and environmental issues into core business operations, formulating long-term plans, controlling and measuring performance on such issues by organisations and communicating them to organisational stakeholders (Zvezdov et al. 2010). Thus, in addition to the conventional corporate financial reporting, SAR includes reporting on environmental, health, safety and other social issues to relevant and broader scope of external stakeholders. SAR, in this regard, is contended to be an extension or modification to companies accounting systems designed to promote a strategy of sustainability and hence part of corporate external reporting system (Sisaye 2011a, 2011b; Gray, 2006).

Extant literature suggests that companies can create long-term value, manage their business risk and gain a competitive advantage by considering the social, environmental and economic impacts of their business operations relative to solely emphasising corporate profit (Asif et al. 2011; Herzig and Schaltegger 2011; Porter, 2003). Companies therefore engage in SAR to better manage and communicate their business risk and create and enhance long-term shareholder value. ${ }^{5}$ It is suggested that, principal actors of the corporate environment, including employees, businesses, industries and government, play an integrative role in this firm value creation process by linking company strategy to sustainability, evaluating risks and opportunities, and providing measurement, accounting and reporting skills (Zvezdov et al. 2010; Evans et al. 2011). In this regard, if SAR is assumed to be a way that firms internalise and manage sustainability needs to make it measurable and observable, then the role of accountants in ensuring useful SAR and assurance practices, to create corporate value cannot be overemphasised.

\section{SAR and the accountant}

Traditionally, corporate accountants are mainly responsible for the provision of accounting information structured to measure, observe and assess business activities and their results (Özsözgün Çalişkan 2014). They also verify financial data, assess compliance status, undertake cost-benefit analysis and ensure the practical design and implementation of organisational internal control systems. Accountants are, thus, mandated to provide reliable, timely and useful information to guide, direct and protect the interests of stakeholders (Aras and Crowther 2009a, 2009b). Impliedly, accountants have the skills and expertise to value environmental impact, evaluate environmental performance and monitor the entire environmental management system of companies as this falls within their purview (Wilmshurst and Frost 2001). For instance, accountants are better equipped to identify and measure the direct and indirect social and environmental costs financially and develop practical consumption-based measures of current and future social and environmental performance required in green accounting (Vincent, 2000). Wilmshurst and Frost (2001) therefore contend that accountants can ensure the successful implementation of the environmental management system by inculcating the traditional functions of accounting into the environmental management process.

Accountants also provide auditing and assurance service, which involves assessment of compliance with standards and regulations, identification and evaluation of risks and attesting to the reliabilities of the information provided (Özsözgün Çalişkan 2014). In the context of 
SAR, accountants could play a significant role in socio-environmental performance via environmental auditing, i.e., assessing compliance, evaluating environmental risks and providing feedback for continuous improvement of firm's sustainability policies and performance (Wilmshurst and Frost 2001). For example, accountants are likely to be responsible for developing an information and decision support systems to ensure environmental compliance and avoid any environmental disputes or claims in the future (Bisk CPA Review Editorial Team, 2012). Suggestively, the expertise of professional accountants to verify financial information makes them better placed in assessing and verifying the compliance status and the economic viability of environmental management accounting systems.

In sum, accountants can provide the needed expertise for developing and verifying information, decision supporting and control system necessary for the provision of both financial information and non-financial information, including sustainability reports, to enhance managerial decisions for creating long-term firm value (Aras and Crowther 2009b; Sisaye and Birnberg 2010). These specific roles of the accountant, coupled with their ability to establish and interpret connections between non-financial and financial information of firms and responsibility to inform and educate related parties (Özsözgün Çalişkan 2014), suggest the crucial part they play in effective corporate SAR practices. ${ }^{6}$ Thus, for companies to improve their financial, social, and environmental performance reporting, accountants must be active in SAR to provide such comprehensive accounting information (Lusher 2012). This provides a massive opportunity for accountants to spearhead environmental and sustainability management via their active involvement in the SAR process (Lewis 2000).

It has been argued that the attitude of top-level managers is very relevant in formulating sustainability goals and the communication of sustainability information (Schaltegger and Wagner 2006). Hence, if top management is uncertain about the relevance of SAR reporting, they may not commit resources to ensure its implementation thereby hindering the practice of SAR in an organisation (Martin and Hadley 2008). The authority that accountants have in organisations (Dezaley and Sugarman 1995) because of the formally established access they have to essential decision-makers cannot be overemphasised. Accountants are deemed information providers to corporate decision-makers, including top management, if not top managers themselves in organisations. The influential role of the accountant as information broker has made them internal business consultants (Burns and Vaivio 2001) and business advisors (Francis and Minchington 1999). This suggests that accountants potentially influence corporate management decisions to engage in SAR because of their information brokerage role for firms' top management.
Notwithstanding the fact that studies have generally found the attitudes of top managers, including accountants towards the environment to be positive (Kuasirikun 2005; Lodhia 2003; O’Dwyer 2002; Wilmshurst and Frost 2001), the willingness of accountants to engage in environmental and sustainability reporting has been questioned (Deegan and Rankin 1996; Gray et al. 1995). This explains why in recent times there have been calls for accountants to be more involved in SAR and other environmental sustainability management issues (Evans et al. 2011). Gray et al. (2010) call for the need for researchers to investigate why key managers such as accountants do not support and help develop social and environmental accounting. While acknowledging the fact that some works have been done in responding to this call, especially in examining the attitudes of accountants and other top managers towards SAR, research on SAR from the perspective of developing countries is still at the infant stage (Thoradeniya et al. 2015). Motivated by the need for more studies into SAR within the context of developing countries, this study explores the perception of accountants on their companies' intentions towards SAR and investigates the main predictors of such intentions. The next section discusses the theoretical review and the primary hypotheses to be tested.

\section{Theoretical review and hypotheses development Theory of planned behaviour (TPB)}

The Theory of Planned Behaviour (TPB) is one of the most influential and well-recognised theories applied in psychological research to predict and explain human behaviour. TPB is an extension of the Theory of Reasoned Action (TRA) (Ajzen and Fishbein 1980; Ajzen, 1988). While the TRA posits that attitudes and subjective norm are the critical determinants of intentions and behaviour, TPB considers 'perceived behavioural control' as an additional variable that predicts intentions and behaviour. Therefore, from the tenets of TPB, attitude, subjective norm and perceived behavioural control are the factors that influence an individual's behavioural intention which informs the individual's motivation to perform the behaviour.

Ajzen (1991) explained attitude to mean the extent to which an individual has a favourable or unfavourable evaluation of behaviour. Subjective norm is an individual's perception of the opinions of some prominent individuals who influence decisions of the individual. In other words, subjective norm describes the tendency for an individual to exhibit a behaviour based on the influences of people considered to be important within the immediate community. Perceived behavioural control is also explained to mean the perception that an individual has about his/her own ability to perform a particular behaviour. Thoradeniya et al. (2015) explain perceived behavioural control to 
mean a situation where an individual lacks the complete control to exercise and perform a behaviour.

As Thoradeniya et al. (2015) rightly indicate - although the actions of persons, in general, are influenced by the data they process and act upon regularly - their actions are also influenced to, a considerable extent, by the availability of resources to perform the act and by external forces who have major influence. A significant distinction between the TPB and the TRA therefore lies in the fact that TRA does not consider the effect of resource availability on the performance of an action by an individual. In sum, from the perspective of the TPB, performance of actual behaviour by an individual depends on the attitude of the individual towards the behaviour, the influence of other important people in society on the behaviour of the invididual and the capacity of the individual to perform the behaviour.

Due to its usefulness in explaining the intentions and behaviour of individuals, the current study relies on the TPB to examine the factors that influence professional accountants' intentions to engage in sustainability reporting practices. Specifically, the study investigates whether professional accountants' attitude towards sustainability reporting (attitude), their perception of sustainability reporting approval by stakeholders (subjective norm), and the perception of their ability to control the process of sustainability reporting (perceived behavioural control) are important predictors of intentions to engage in SAR. Three main hypotheses based on the tenets of the TPB are consequently developed as follows:

\section{Hypotheses development}

\section{Attitude towards SAR and intention to engage in SAR}

Attitude is a key antecedent of intention to act and reflects a person's overall assessment of an issue at hand (Weidman et al. 2010). Fishbein \& Ajzen, (1975) view it as the best predictor of intention and behaviour. Prior studies provide evidence that a manager's attitude has important implications on social-environmental issues and SAR practices (Adams 2002; Beddewela and Herzig 2013; Cordano and Frieze 2000; Thoradeniya et al. 2015; Weidman et al. 2010). These studies predict and consistently report of a positive association between attitude and intentions of firm managers to engage in SAR. Cordano and Frieze (2000) for instance, find the intention of managers to prevent pollution and source reduction activities to be positively related to their attitudes whiles Weidman et al. (2010) find that the attitude of firm executives have a positive relationship with their intentions to accrue and disclose environmental liabilities in the US.

Thoradeniya et al. (2015) find a similar relationship between managers' attitudes and intention to engage in SAR in Sri Lanka while Farzana et al. (2015) document that attitude is an important determinant of the energy conservation intention of accounting students in
Malaysia. Notwithstanding the fact that some studies including Flannery and May (2000) report a negative association between internal perceived behavioural control and managers' environmental, ethical decision intentions, the evidence provided by most empirical studies generally suggest the existence of a positive relationship between attitudes and intention. Hence this study hypothesises that.

\section{$H_{1}$ There is a positive relationship between accountants' attitude and their intention to engage in SAR.}

\section{Subjective norm and intention to engage in SAR}

Subjective norm, which is an individual's perception of the opinions of prominent people who maintain influence over decision making, can affect an individual's intention to perform or not perform an action (Ajzen 1991). Corporate actions and inactions affect stakeholders and society, and the need to perform and report on these actions has been raging on in the academic environment. Existing literature documents that major stakeholders of companies - prospective employees, existing and potential capital providers/investors, the public/society, regulators and environmental pressure groups influence the SAR behaviour of firms (Dillard et al. 2005; Hedberg and Von Malmborg 2003; Magness 2006) This suggests the influence of key stakeholders on companies. These companies are obliged to act and perform to protect their image and reputation to sustain their business, although it may be costly. SAR in Ghana currently is a discretionary activity and mindful of cost, managers are unlikely to practice and report on it. Hence, pressure from stakeholders considered vital to the business may encourage managers to consider such an action.

Some studies report of how subjective norm (key stakeholders) influences the intentions of managers to engage in SAR (Weidman et al. 2010; Cordano and Frieze 2000; Flannery and May 2000; Thoradeniya et al. 2015). For example, Weidman et al. (2010) find that the intentions to accrue and disclose environmental liabilities by financial executives are positively related to their subjective norms. Similarly, Cordano and Frieze (2000) document a positive relationship between subjective norm and environmental managers' intention to engage in source reduction activities to prevent pollution. Flannery and May (2000) also find subjective norm to be a significant predictor of managers' environmental, ethical decision intentions. Again, Thoradeniya et al. (2015) find a positive relationship between managers' subjective norm and their intention to engage in sustainability reporting. Based on the seeming power of stakeholders to influence intention to act, this study posits that.

$\mathrm{H}_{2}$ There is a positive relationship between subjective norm and intention to engage in SAR. 


\section{Perceived Behavioural control and intention to engage in SAR}

Perceived behavioural control which is the perception that an individual has about his/her own ability to perform a specific behaviour influences the intention to perform that particular behaviour (Ajzen 1991). The ability to perform a particular behaviour depends on the availability of resources. Resources are thus vital to management intention and actions and managers will consider actions that are beneficial to them. Intention to engage in SAR will involve consideration by managers of resource availability and skills to perform the activity. The extant literature identifies some factors that facilitate or inhibit the managers' control and their willingness to engage in SAR. This includes knowledge, skills, and experience of managers; the availability of time and resources; continuous training and improvement; and effective cooperation and communication with external stakeholders.

Whereas Adams and McNicholas (2007); Lamberton (2005) and Park and Brorson (2005) suggest that availability of time and resources; increased knowledge and expertise enhance SAR process; they also argue that lack of support by management through sound leadership, ineffective cooperation and communication between all parties involved in the process and the absence of continuous training and development may inhibit the SAR process. Professional accountants by their training are exposed to SAR and may be willing to engage in it. However, where systems and structures are non-existent, they cannot do much. The discretionary nature of SAR, coupled with the cost implication of implementing a useful structure and system may affect the intention of managers to engage in SAR, and this is rightly so in Ghana. Professional accountants may be willing to engage in SR but considering its voluntary nature and the cost implication on profit, they may not have the support from other management personnel to engage in it especially where this is not aligned to their interest.

Results of studies on perceived behavioural control and intention to engage in SAR and other environmental activities are mixed. For instance, Weidman et al. (2010) find that the intentions to accrue and disclose environmental liabilities by financial executives are positively related to their perceived behavioural control. Also, Thoradeniya et al. (2015) find a positive relationship between managers perceived behavioural control and their intention to engage in sustainability reporting. Lee et al. (2017) document that perceived behavioural control positively and significantly influences students' positive intentions towards the environment. On the other hand, Cordano and Frieze (2000) report of a negative relationship between perceived behavioural control environmental managers' intention to engage in source reduction activities to prevent pollution. Similarly, Flannery and May (2000) find a negative relationship between internal perceived behavioural control and managers' environmental, ethical decision intentions. However, this study posits a direct link between the constructs.

\section{$\mathrm{H}_{3}$ There is a positive relationship between accountants perceived behavioural control and their intention to engage in $S A R$.}

\section{The development of the accounting profession in Ghana and the need for sustainability studies}

Ghana after gaining independence in 1957, the national spirit of the time was for the nation to achieve optimum development in all facets of the Ghanaian human life. There was also a clarion call by the average Ghanaian to develop local capacity. Around that same time, the country was experiencing severe difficulties with regards to the training of accountants. These difficulties were as a result of inadequate local practical experience for accountancy trainees. This consequently led to the establishment of a local accountancy professional body called the Institute of Chartered Accountants - Ghana (ICAG). The ICAG was established by an Act of Parliament, Act 170, in 1963. It is the sole body responsible for regulating the accountancy profession in Ghana. The members of the Institute are the only persons recognized under the Companies Code 1963 (Act 179) for the purpose of the audit of a company.

The institute is governed by a Council of eleven chartered accountants headed by a president who holds office for a period of 2 years. The ICAG is a member of three international bodies namely: the International Federation of Accountants (IFAC), Pan African Federation of Accountants (PAFA) and Association of Accountancy Bodies in West Africa (ABWA). The ICAG currently runs three distinct programmes: the professional Chartered Accountants (CA) programme, the Accounting Technicians Scheme West Africa which provides the avenue for graduates to take up middle-level managerial jobs and the Chartered Diploma programmes which are designed to enable members specialize in specific business - related disciplines. Since its inception, the institute has been instrumental in training and licensing a number of qualified accountants to meet the industry's ever-growing demand for professional accountants. Within the last decade, the number of chartered accountants in Ghana has witnessed significant growth. For instance, between the year 2004 and 2014, the number of professional accountants increases from 1089 to 3851 respectively (ROSC, 2014). Notwithstanding the huge growth in the numbers, demand for professional accountants in the country which is estimated around 8000 far exceeds the supply.

In a bid to improve upon the reporting quality in the country and promote cross-border comparison of 
accounting information and within the spirit of harmonization, the government through the institute adopted the International Financial Reporting Standards (IFRS) in the year 2007. Thus, Ghana just like many other countries has fully adopted the IFRS for reporting purposes. The adoption of the IFRS was in part influenced by a review of Accounting and Auditing practices in Ghana conducted in 2004 by the World Bank. The World Bank documented the issues found in its Report on Observance of Standards and Codes (ROSC). Among other things, the report highlighted the weaknesses and strengths of the accounting and auditing requirements as pertained in the then Ghana National Accounting Standards (GNAS) and strongly recommended the full adoption of IFRS to replace the GNAS.

Apart from the fact that the country Ghana has made progress in the development of its accounting profession, Ghana provides a very good setting for sustainability related studies in an African setting. The country remains one of African countries with rich in natural resources including gold, diamond, bauxite with the latest being the discovery of oil in commercial quantities. In fact, Ghana contributes significantly to the world's gold production as it ranks tenth in the world's leading producers of gold and ranks second in Africa (Kapstein and Kim 2011). In spite of Ghana's contribution, a whopping $85 \%$ of artisanal and small-scale miners' activities are illegal, unregulated and therefore inimical to the environment and society at large (Ofosu-Mensah 2016). Similarly, Abdulai (2017) bemoans the severe nature of illegal mining in Ghana and calls for political action to deal with the menace. The relevance of sustainability practice in this setting therefore cannot be overemphasized.

\section{Methodology}

\section{Research design and data collection}

The study employed the survey research method and the data employed was obtained from a set of questionnaires. The survey instrument for the study contained two different sections - questions on the essential demographic characteristics of the respondents including the age, gender type, level of education, a sector of employment, number of years of employment and the position held by the respondents in their respective organisations at the time of the survey. The second part of the questionnaire sought to measure respondents' intentions to engage in SAR and the dominant factors that influence this intention.

Based on the TPB, three constructs: attitude, subjective norm and perceived behavioural control were the primary factors considered in this study as influential on companies' intention to engage in SAR. Each of these constructs was measured on a seven-point Likert scale with multiple indicators describing each construct. Similar to Thoradeniya, all the constructs were measured using four indicators each. The indicators for attitude measures the professional accountants' personal views on their company's engagement in SAR, whiles indicators for subjective norm focused on the professional accountants' perception about stakeholders' approval or otherwise of their company engaging in SAR. For perceived behavioural control, indicator questions seek to obtain information on the ability of the firms to perform the act, i.e. SAR and who determines the performance of the act.

Respondents were required to state their level of agreement or otherwise based on the seven-point Likert scale with one being strongly disagreed and seven being strongly agreed. The specific questions used in measuring the constructs were adopted from an earlier study by Thoradeniya et al. (2015). This instrument was considered more appropriate for use in this study since it was developed based on many of the existing instruments and hence, results from this study could be compared with most empirical studies with minimal difficulty.

The instrument was administered to the respondent group at a conference marking forum organised by ICA-GH. This forum offered the researchers the unique opportunity of reaching out to accountants in good standing with the Institute of Chartered Accountant Ghana (ICA-GH) from different organisations (both public and private sector) across the country at a central location. A few of the questionnaire was also sent to accounting firms and organisations that were not represented in this sample during the conference marking. In all, a total of 120 questionnaires were administered to the respondent group during the conference marking seminar of professional accountants in June 2016 and subsequently to other accountants in July 2016. Out of the number of questionnaires administered, 86 of the respondents responded to the questionnaire representing a response rate of $71.6 \%$.

\section{Data analysis procedures}

In examining the objectives of the study, the partial least square (PLS) structural equation modelling (SEM) technique was adopted. The PLS model, a variance based technique of SEM was employed as it permits analysis of both direct and indirect relationships between independent and dependent variables and also allows for minimal path construction (Fornell and Bookstein 1982). Moreover, PLS does not require a large sample size and therefore, handles better data that are not normally distributed (Gefen and Straub 2005; Hair Jr et al. 2014; Henseler et al. 2009). Thus, given that the sample size for the study was relatively small, the PLS technique was deemed more appropriate for this study.

\section{Results and discussions Descriptive statistics}

Table 1 presents the essential demographic profile of the respondents used in the study analysis. Out of the total 
86 respondents, 66 were males $(77 \%)$ with the remaining $20(23 \%)$ of the sample being females. Among all the respondents, 78\% hold positions from supervisory level up to senior management level while $30 \%$ of them had working experience of 5-10 years and $26 \%$ had work experience of more than 10 years. This result is a clear indication that a sizeable number of the respondents occupy higher level management positions and have also acquired a significant amount of working experience in their respective organisations hence, their views could reasonably be relied upon for a study of this nature. The presumption is that, because of the key position these respondents (accountants) hold in their organization, their role is crucial in the development of sustainability strategy for their respective companies and hence, their views/position on sustainability issues may be a fair reflection of their organizations.

\section{Initial measurement model assessment}

Before proceeding with the structural model analysis, the measurement characteristics of the constructs and their indicators were assessed to determine whether they meet the recommended thresholds suitable for the structural analysis. An examination of the indicator loadings as shown in Table 2 demonstrate that all the indicators for the constructs were above the 0.70 recommended threshold and hence can be reasonably classified as good indicators (Sarstedt et al. 2014). Indicator loadings above
0.70 according to Sarstedt et al. (2014) means that the construct explains more than $50 \%$ of the indicator's variance which is considered appropriate for structural model analysis.

Internal consistency reliability of the constructs was also checked using Cronbach alpha and composite reliability, and the results are presented in Table 3. As shown in Table 3, composite reliability scores for each of the study construct exceeded 0.70 minimum requirement (Hair Jr et al. 2014; Sarstedt et al. 2014), while the Cronbach alpha coefficients were all above the minimum 0.70 thresholds (Nunnally 1978). Further, convergent validity and the discriminant validity tests were conducted on the study constructs.

Convergent validity test was carried out using the average variance extracted (AVE) for all items related to each of the constructs. This test is conducted to ensure whether the set of indicators represents the same underlying construct. An AVE of 0.50 and above is considered acceptable as a value of 0.50 and above is an indication that more than $50 \%$ of the variance of the items are explained by the construct (Hair Jr et al. 2014; Sarstedt et al. 2014). As shown in panel A of Table 3, the AVE scores for all the constructs were above 0.50 which indicates that convergent validity is assured.

Discriminant validity test was also conducted to ascertain whether the study constructs were distinct from each other in the path model using the Fornell-Larcker

Table 1 Demographic Characteristics of Respondents

\begin{tabular}{|c|c|c|c|c|}
\hline Age & $21-30$ years & $31-40$ years & $41-50$ years & Over 50 years \\
\hline Frequency & 29 & 29 & 19 & 9 \\
\hline Percentage & $34 \%$ & $34 \%$ & $22 \%$ & $10 \%$ \\
\hline Gender & Male & Female & & \\
\hline Frequency & 66 & 20 & & \\
\hline Percentage & $77 \%$ & $23 \%$ & & \\
\hline Highest Education & $\begin{array}{l}\text { Bachelors and Professional } \\
\text { Certificate }\end{array}$ & $\begin{array}{l}\text { Bachelors, Masters and Professional } \\
\text { certificate }\end{array}$ & $\begin{array}{l}\text { Professional Certificate } \\
\text { only }\end{array}$ & \\
\hline Frequency & 32 & 49 & 5 & \\
\hline Percentage & $37 \%$ & $57 \%$ & $6 \%$ & \\
\hline Type of organisation & Public Sector & Public Accounting Firm & Private Accounting Firm & Private Sector \\
\hline Frequency & 24 & 11 & 36 & 15 \\
\hline Percentage & $28 \%$ & $13 \%$ & $42 \%$ & $17 \%$ \\
\hline Position in company & Junior staff & Supervisory management & $\begin{array}{l}\text { Middle level } \\
\text { management }\end{array}$ & $\begin{array}{l}\text { Senior level } \\
\text { management }\end{array}$ \\
\hline Frequency & 19 & 35 & 26 & 6 \\
\hline Percentage & $22 \%$ & $41 \%$ & $30 \%$ & $7 \%$ \\
\hline $\begin{array}{l}\text { Years spent with } \\
\text { organisation }\end{array}$ & Below 5 years & $5-10$ years & $10-20$ years & above 20 years \\
\hline Frequency & 38 & 26 & 17 & 5 \\
\hline Percentage & $44 \%$ & $30 \%$ & $20 \%$ & $6 \%$ \\
\hline
\end{tabular}


Table 2 Indicator Loadings

\begin{tabular}{|c|c|}
\hline Variable & Loading \\
\hline \multicolumn{2}{|l|}{ Intentions (INT) } \\
\hline My company is committed to engage in or continue SAR & 0.93 \\
\hline My company plans to engage in or continue SAR & 0.95 \\
\hline My company has the intention to engage in or continue SAR & 0.94 \\
\hline My company is willing to engage in or continue SAR & 0.87 \\
\hline \multicolumn{2}{|l|}{ Attitudes (ATT) } \\
\hline It is good for my company to engage in Sustainability Reporting & 0.86 \\
\hline It is rewarding for my company to engage in SAR & 0.97 \\
\hline It is valuable for my company to engage in SAR & 0.97 \\
\hline It is meaningful for my company to engage in SAR & 0.78 \\
\hline \multicolumn{2}{|l|}{ Subjective norm (SBN) } \\
\hline Most of my company's stakeholders (shareholders, employees, community, etc.) think that my company should engage in SAR & 0.93 \\
\hline Most of the internal stakeholders (employees and management) would approve my company engaging in SAR & 0.72 \\
\hline Most organisations, whose opinions are valued by my company, engage in SAR & 0.90 \\
\hline Many companies similar to my company engage in SAR & 0.88 \\
\hline \multicolumn{2}{|l|}{ Behavioural control (BC) } \\
\hline It is easy for my company to engage in SAR & 0.79 \\
\hline It is possible for my company to engage in SAR & 0.76 \\
\hline The decision to engage in SAR is under my company's authority & 0.76 \\
\hline The decision to engage in SAR is under my company's control & 0.85 \\
\hline
\end{tabular}

criterion (Fornell and Larcker 1981). This criterion compares the AVE of each construct with the squared inter-construct correlation of that construct with all other constructs in the model. As can be seen from panel B of Table 3, the various square roots of the AVEs for each construct (in bold) are far higher than the inter-item correlation coefficients which demonstrate that discriminant validity criteria have been fulfilled. The above results demonstrate that the measures for the study constructs are reliable and valid to perform the structural model analysis.

Table 3 Reliability and Valid Tests

\begin{tabular}{|c|c|c|c|c|}
\hline \multicolumn{5}{|c|}{ Panel A: Convergent Validity and Reliability Test } \\
\hline & AVE & Composite Reliability & \multicolumn{2}{|c|}{ Cronbach's Alpha } \\
\hline ATT & 0.80 & 0.94 & \multicolumn{2}{|l|}{0.92} \\
\hline $\mathrm{BC}$ & 0.63 & 0.87 & \multicolumn{2}{|l|}{0.80} \\
\hline INT & 0.85 & 0.95 & \multicolumn{2}{|l|}{0.94} \\
\hline SBN & 0.74 & 0.92 & \multicolumn{2}{|l|}{0.88} \\
\hline \multicolumn{5}{|c|}{ Panel B: Discriminant Validity Test } \\
\hline & ATT & $B C$ & \multirow[t]{3}{*}{ INT } & \multirow[t]{4}{*}{$S B N$} \\
\hline ATT & 0.90 & & & \\
\hline BC & 0.48 & 0.79 & & \\
\hline INT & 0.49 & 0.60 & 0.92 & \\
\hline SBN & 0.52 & 0.53 & 0.75 & 0.86 \\
\hline
\end{tabular}

\section{Structural model analysis}

The study initially examined if collinearity was present among the constructs (predictors) - attitude (ATT), subjective norm $(\mathrm{SBN})$ and perceived behavioural control (BC) to determine the structural relationship among the study constructs. This test is essential since the structural path coefficient for the model is based on ordinary least squares (OLS) regression (Mooi and Sarstedt 2011). Collinearity test was conducted using the Variance Inflation Factor (VIF). The results from this test raise no general concern about collinearity problems given that the VIF values which range between 2.08 and 2.59 are far below the maximum threshold of 10 . The low VIF values are indicative of the fact that the results from the structural model analysis are not influenced negatively by collinearity problems. Having ensured the reliability and validity of the construct, the proposed hypotheses were examined by running Algorithm and Bootstrapping of SmartPLS. Figure 1 and Table 4 present the products of the algorithms.

Test of the overall model quality was assessed using the coefficient of determination $\left(R^{2}\right)$. The $R^{2}$ indicates the predictive power of the endogenous constructs by showing the percentage of variance explained (Sarstedt et al. 2014). The result of this test as shown in Fig. 1 demonstrates that the endogenous construct 'Intention to engage in sustainability reporting (SAR) has a high predictive power given 


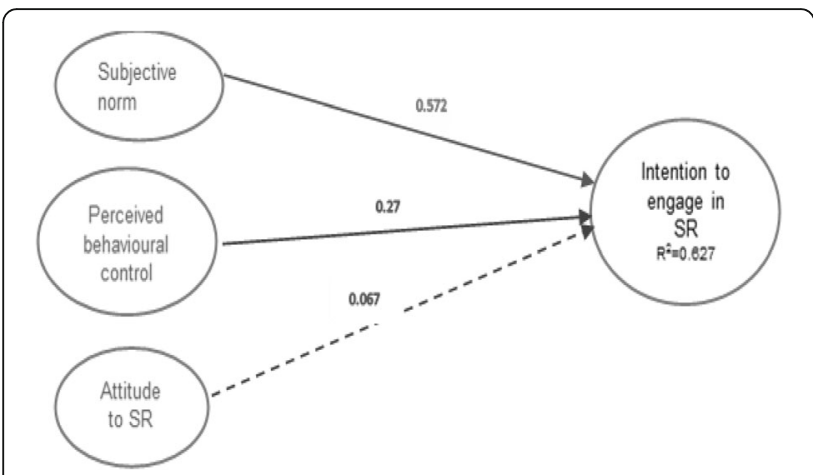

Fig. 1 Structural Model for Intention to Engage in SAR

the reported $R^{2}$ value of 0.627 . By implication, $62.7 \%$ of Intention to engage in sustainability reporting is jointly explained by all the exogenous variables. Next, the predictive relevance of the endogenous construct for the model was evaluated by adopting Hair Jr et al. (2014) blindfolding guidelines. The rule of thumb is that the cross-validated redundancy $\left(\mathrm{Q}^{2}\right)$ should be above zero to be considered relevant. The result from this test also provides enough support for the predictive relevance of the endogenous construct 'Intention to engage in SAR' with a $Q^{2}$ value of 0.5136.

Finally, the coefficient and significance of the paths in the structural model were analysed using bootstrapping procedure. These paths demonstrate the original hypotheses or the structural relationships of the study as shown in Fig. 1 and Table 4. In this study, we predicted that professional accountants' attitude (ATT), subjective norm (SBN) and perceived behavioural control (BC) have a direct influence on a company's intention to engage in SAR as espoused by Thoradeniya et al. (2015) and Weidman et al. (2010). However, the results from the path analysis (Fig. 1) indicate that only two of the indicator constructs - subjective norm and perceived behavioural control have a significant relationship with intention to engage in SAR. With a path coefficient of $0.572(p$ value $=0.000)$, subjective norm was found to have a significant positive relationship with perception about a company's intention to engage in SAR. Likewise, perceived behavioural control was also found to be positively and significantly related to intention to engage in SAR with a path coefficient of 0.27 ( $p$ value $=0.000$ ). The relationship between accountants' attitude towards SAR and intentions recorded insignificant results with a path coefficient of 0.067 and a $p$-value of 0.40 .

Table 4 Structural model results

\begin{tabular}{lllll}
\hline Hypothesis & Path & Path Co-efficient & $p$ value & Decision \\
\hline $\mathrm{H} 1$ & $\mathrm{ATT} \rightarrow$ INT & 0.067 & 0.40 & Rejected \\
$\mathrm{H} 2$ & $\mathrm{SBN} \rightarrow$ INT & 0.27 & 0.00 & Supported \\
$\mathrm{H} 3$ & $\mathrm{BC} \rightarrow$ INT & 0.527 & 0.00 & Supported \\
\hline
\end{tabular}

The above results suggest that perceived pressure from major stakeholders of a firm by accountants and the availability of resources are the key determinants of intentions to engage in SAR. The findings of this study indicate that the personal attitude of accountants towards SAR do not affect the company's intention to engage in SAR in a significant way. Impliedly, regardless of the predisposition of accountants towards SAR, a firm is more likely to engage in SAR when it has the much-needed resources to invest into it and when stakeholders exert pressure and demand for such information. Thus, irrespective of an accountant's disposition towards SAR, pressure from stakeholders for such information and availability of resources to provide same may trigger action from management to engage in SAR to avoid legitimacy threats from these stakeholders.

The results, to a considerable extent, are expected. Given that SAR remains mostly a voluntary activity and a drain on shareholder wealth, availability of resources would be a significant consideration for firms to engage in the practice. Moreover, since there would always be competing demands for the resources of firms which are usually scarce (Lamberton 2005; Adams and McNicholas 2007), the intention to engage in SAR will also be dependent in part on pressure from users of such information. From empirical perspective except for the insignificant relationship between attitude and intention to engage in SAR, our findings are broadly consistent with the work of Thoradeniya et al. (2015) and Weidman et al. (2010). Nevertheless, the insignificant relationship between attitude and intentions from this study has also received empirical support in past studies (Flannery and May 2000).

\section{Conclusion}

The study examined the primary determinants of the intention to engage in SAR in Ghana from the perspective of professional accountants. Based on the tenets of TPB, the study examined the attitude of professional accountants, their perception of perceived behavioural control and subjective norm on their company's intention to engage in SAR. Using the instrument of Thoradeniya et al. (2015), data was collected from accountants who belong to the professional accounting body ICA-GH for the empirical analysis of the study. The partial least square (PLS) SEM-based technique was adopted to analyse the study objectives.

Based on the results from the structural model, the study found that two of the constructs: perceived behavioural control and subjective norm are the main predictors of a firm's intention to engage in SAR. Thus, the intention to engage in SAR is primarily influenced by stakeholder pressure for disclosure of such information and availability of resources to engage in the practice. However, the attitude of professional accountants towards SAR does not influence the intention to engage in SAR significantly. Given that 
resources of the firm are scarce in relations to the unlimited needs, an essential way of promoting the SAR based on the findings of this study will be for significant stakeholders to be alive with their responsibilities and exert pressure on corporations to disclose information on sustainability. Notwithstanding the key contributions of the present study to the SAR literature the findings are based on the views of very few professional accountants in Ghana. While this limitation may affect the extent of generalization of the study findings, it also provides an important avenue for further research in the area in different context.

\section{Endnotes}

${ }^{1}$ Defined as the process through which firms provide information on the socio-economic and environmental impacts of their operations to stakeholders.

${ }^{2}$ This assertion assumes that financial accounting reports can serve the legal and administrative regulations and persons with economic power in support of liberal economic democracy, a grounded theory of financial reporting (Gray, 2006; Özsözgün Çalişkan 2014)

${ }^{3}$ Reports on environmental, health and safety often include issues on employee health, on-the-job accident rates, emissions of certain pollutants, spills, volumes of waste generated and initiatives to reduce and minimise such incidents and releases. Social issue reporting embraces reports on ethical labour practices, training, education and diversity of work force, and corporate philanthropic initiatives.

${ }^{4}$ Lin et al. (2008) assert that the perceptions about a practice is essential in establishing the knowledge and acceptance of the practice.

${ }^{5}$ Other indirect firm value creation variables such as legitimising corporate actions, enhancing and protecting companies reputation, demonstrating firms' commitment to the environment and social issues, and response to demands for information from the growing number of stakeholders are also advanced as contributing to the practice of SAR by firms (Özsözgün Çalişkan 2014; Schaltegger and Burritt 2010).

${ }^{6}$ See Özsözgün Çalişkan (2014) and Schaltegger and Zvezdov (2015) for a detailed review and discussion of the role of accounting and accountant in SAR.

\section{Abbreviations \\ ATT: Attitude; AVE: Average variance extracted; BC: Perceived behavioural control; GNAS: Ghana national accounting standards; ICAG: Institute of chartered accountants-Ghana; IFAC: International federation of accountants; KPMG: Klynveld Peat Marwick Goerdeler; OLS: ordinary least squares; PAFA: Pan African Federation of Accountants; PLS: Partial least square; ROSC: Report on Observance of Standards and Codes; SAR: Sustainability Accounting Reporting; SBN: Subjective norm and; SEM: Structural Equation Modelling; TBL: Triple Bottom Line; TPB: Theory of Planned Behaviour; TRA: Theory of Reason; VIF: Variance Inflation Factor}

\section{Availability of data and materials}

All data generated or analysed during this study are included in this published article. The raw data set used and/or analysed during the current study are available from the corresponding author on reasonable request.
Authors' contributions

All authors read and approved the final manuscript.

\section{Competing interests}

The authors declare that they have no competing interests.

\section{Publisher's Note}

Springer Nature remains neutral with regard to jurisdictional claims in published maps and institutional affiliations.

Received: 25 January 2018 Accepted: 6 August 2018

Published online: 22 August 2018

\section{References}

Abdulai, A.-G. (2017). The galamsey menace in Ghana: A political problem requiring political solutions. Accra: University of Ghana Business School Policy Brief 5.

Adams, C. A. (2002). Internal organisational factors influencing corporate social and ethical reporting: Beyond current theorising. Accounting, Auditing \& Accountability Journal, 15(2), 223-250.

Adams, C. A., \& McNicholas, P. (2007). Making a difference: Sustainability reporting, accountability and organisational change. Accounting, Auditing \& Accountability Journal, 20(3), 382-402.

Adams, C. A., \& Whelan, G. (2009). Conceptualising future change in corporate sustainability reporting. Accounting, Auditing \& Accountability Journal, 22(1), 118-143.

Ajzen, I. (1988). Attitudes, Personality and Behaviour. Milton Keynes: Open University Press.

Ajzen, I. (1991). The theory of planned behavior. Organizational Behavior and Human Processes, 50(2), 179-211.

Ajzen, I., \& Fishbein, M. (1980). Understanding attitudes and predicting social behaviour.

Albelda, E. (2011). The role of management accounting practices as facilitators of the environmental management: Evidence from EMAS organisations. Sustainability Accounting, Management and Policy Journal, 2(1), 76-100.

Aras, G., \& Crowther, D. (2009a). Corporate sustainability reporting: A study in disingenuity? Journal of Business Ethics, 87(1), 279.

Aras, G., \& Crowther, D. (2009b). Making sustainable development sustainable. Management Decision, 47(6), 975-988.

Asif, M., Searcy, C., Garvare, R., \& Ahmad, N. (2011). Including sustainability in business excellence models. Total Quality Management and Business Excellence, 22(7), 773-786.

Ball, A., Owen, D. L., \& Gray, R. (2000). External transparency or internal capture? The role of third-party statements in adding value to corporate environmental reports 11. Business Strategy and the Environment, 9(1), 1-23.

Bebbington, J., \& Gray, R. (2001). An account of sustainability: Failure, success and a reconceptualization. Critical Perspectives on Accounting, 12(5), 557-587.

Beddewela, E., \& Herzig, C. (2013). Corporate social reporting by MNCs' subsidiaries in Sri Lanka. Accounting Forum, 37(2), 135-149.

Belal, A. R., \& Owen, D. L. (2007). The views of corporate managers on the current state of, and future prospects for, social reporting in Bangladesh: An engagement-based study. Accounting, Auditing \& Accountability Journal, 20(3), 472-494.

Bennett, M. D., Schaltegger, S., \& Zvezdov, D. (2013). Exploring corporate practices in management accounting for sustainability. London: ICAEW.

Bisk Editorial Review Team. (2012). Top 5 (surprise!) CPA job opportunities. New Accountant, 749 (6-8).

Burns, J., \& Vaivio, J. (2001). Management accounting change. Management Accounting Research, 12(4), 389-402.

Burritt, R. L., \& Schaltegger, S. (2010). Sustainability accounting and reporting: Fad or trend? Accounting, Auditing \& Accountability Journal, 23(7), 829-846.

Carter, A., Burritt, R., \& Pisaniello, J. (2011). Accountants as mental health workers: The public interest in regional and remote areas. In Paper read at Accounting \& Finance Association of Australia and New Zealand Annual Conference, Danwin, NT.

Cordano, M., \& Frieze, I. H. (2000). Pollution reduction preferences of US environmental managers: Applying Ajzen's theory of planned behavior. The Academy of Management Journal, 43(4), 627-641.

Deegan, C., \& Rankin, M. (1996). Do Australian companies report environmental news objectively? An analysis of environmental disclosures by firms prosecuted successfully by the environmental protection authority. Accounting, Auditing \& Accountability Journal, 9(2), 50-67.

Dezaley, Y., \& Sugarman, D. (1995). Professional competition and professional power: Lawyers, Accountants and the social construction of markets. London: Routledge. 
Dillard, J., D. Brown, and R. S. Marshall. 2005. An environmentally enlightened accounting. Paper read at Accounting Forum.

Evans, E., Burritt, R., \& Guthrie, J. (2011). Bridging the gap between academic accounting research and professional practice. Sydney: The Institute of Chartered Accountants in Australia/Universiy of South Australia.

EY. (2011). How Sustainability Has Expanded the CFO's role. Retrieved from http://www.ey.com/us/en/services/specialty-services/climate-change-andsustainability-services/how-sustainability-has-expanded-the-cfos-role

Farzana, N., Alias, R., Hashim, Z., Daud, S., \& Mariam, S. (2015). Analyzing energy conservation intention among accounting students. The 3rd National Graduate Conference (NatGrad2015), Universiti Tenaga Nasional, Putrajaya Campus, 8-9 April 2015.

Ferreira, A., Moulang, C., \& Hendro, B. (2010). Environmental management accounting and innovation: An exploratory analysis. Accounting, Auditing \& Accountability Journal, 23(7), 920-948.

Fishbein, M., \& Ajzen, I. (1975). Belief, attitude, intention and behavior: An introduction to theory and research.

Flannery, B. L., \& May, D. R. (2000). Environmental ethical decision making in the US metal-finishing industry. The Academy of Management Journal, 43(4), 642-662.

Fornell, C., \& Bookstein, F. L. (1982). Two structural equation models: LISREL and PLS applied to consumer exit-voice theory. Journal of Marketing Research, 19, 440-452.

Fornell, C., \& Larcker, D. F. (1981). Evaluating structural equation models with unobservable variables and measurement error. Journal of Marketing Research, 18, 39-50.

Francis, G., \& Minchington, C. (1999). Quantitative skills: Is there an expectation gap between the education and practice of management accountants? Accounting Education, 8(4), 301-319.

Gefen, D., \& Straub, D. (2005). A practical guide to factorial validity using PLSgraph: Tutorial and annotated example. Communications of the Association for Information Systems, 16(1), 5.

Granlund, M., \& Malmi, T. (2002). Moderate impact of ERPS on management accounting: A lag or permanent outcome? Management Accounting Research, 13(3), 299-321.

Gray, R., Bebbington, J., \& Walters, D. (1993). Accountingfor the environment. London: Paul Chapman Publishing.

Gray, R., Kouhy, R., \& Lavers, S. (1995). Corporate social and environmental reporting: A review of the literature and a longitudinal study of UK disclosure. Accounting, Auditing \& Accountability Journal, 8(2), 47-77.

Gray, R. (2006). Social, environmental and sustainability reporting and organisational value creation? Whose value? Whose creation? Accounting, Auditing \& Accountability Journal, 19(6), 793-819.

Gray, R., Owen, D., \& Adams, C. (2010). Some theories for social accounting?: A review essay and a tentative pedagogic categorisation of theorisations around social accounting. In Sustainability, Environmental Performance and Disclosures (pp. 1-54)

Hair Jr., F. J., Sarstedt, M., Hopkins, L., \& Kuppelwieser, V. G. (2014). Partial least squares structural equation modeling (PLS-SEM) an emerging tool in business research. European Business Review, 26(2), 106-121.

Hedberg, C. J., \& Von Malmborg, F. (2003). The global reporting initiative and corporate sustainability reporting in Swedish companies. Corporate Social Responsibility and Environmental Management, 10(3), 153-164.

Henri, J.F., \& Journeault, M. (2010). Eco-control: The influence of management control systems on environmental and economic performance. Accounting, Organizations and Society, 35(1), 63-80.

Henseler, J., Ringle, C. M., \& Sinkovics, R. R. (2009). The use of partial least squares path modeling in international marketing. In New challenges to international marketing (pp. 277-319). Bingley: Emerald Group Publishing Limited.

Herzig, C., \& Schaltegger, S. (2011). Corporate sustainability reporting. In J. Godemann \& G. Michelsen (Eds.), Sustainability communication (pp. 151-169). Heidelberg: Springer.

Jack, L., \& Kholeif, A. (2008). Enterprise resource planning and a contest to limit the role of management accountants: A strong structuration perspective. Accounting Forum, 32(1), 30-45.

Kamla, R., Gallhofer, S., \& Haslam, J. (2012). Understanding Syrian accountants' perceptions of, and attitudes towards, social accounting. Accounting, Auditing \& Accountability Journal, 25(7), 1170-1205.

Kapstein, E. B., \& Kim, R. (2011). The socio-economic impact of Newmont Ghana gold Limited. Haarlem: Stratcomm Africa.

KPMG. (2011). International survey of corporate responsibility reporting 2011. New York: KPMG International.
Kuasirikun, N. (2005). Attitudes to the development and implementation of social and environmental accounting in Thailand. Critical Perspectives on Accounting 16(8), 1035-1057.

Lamberton, G. 2005. Sustainability accounting - A brief history and conceptual framework. Paper read at Accounting Forum.

Lee, W. E., Birkey, R. N., \& Patten, D. M. (2017). Exposing students to environmental sustainability in accounting: An analysis of its impacts in a US setting. Social and Environmental Accountability Journal, 37(2), 81-96.

Lewis, L. 2000. Environmental audits in local government: A useful means to progress in sustainable development. Paper read at Accounting Forum.

Lin, J. Z., Xiao, J. Z., \& Tang, Q. (2008). The roles, responsibilities and characteristics of audit committee in China. Accounting, Auditing \& Accountability Journal, 21(5), $721-751$.

Lodhia, S. K. (2003). Accountants'responses to the environmental agenda in a developing nation: An initial and exploratory study on Fiji. Critical Perspectives on Accounting, 14(7), 715-737.

Lusher, A. L. (2012). What is the accounting Profession's role in accountability of economic, social, and environmental issues? International Journal of Business and Social Science, 3, 15.

Magness, V. (2006). Strategic posture, financial performance and environmental disclosure: An empirical test of legitimacy theory. Accounting, Auditing \& Accountability Journal, 19(4), 540-563.

Martin, A., \& Hadley, D. (2008). Corporate environmental non-reporting-a UK FTSE 350 perspective. Business Strategy and the Environment, 17(4), 245-259.

Mistry, V., Sharma, U., \& Low, M. (2014). Management accountants' perception of their role in accounting for sustainable development: An exploratory study. Pacific Accounting Review, 26(1/2), 112-133.

Mooi, E., \& Sarstedt, M. (2011). A concise guide to market research, chapter 9: "Cluster analysis". Berlin: Springer-Verlag, 10, 978-3.

Nunnally, J. C. (1978). Psychometric theory. New York: McGraw-Hill.

O'Dwyer, B. (2002). Managerial perceptions of corporate social disclosure: An Irish story. Accounting, Auditing \& Accountability Journal, 15(3), 406-436.

O'Dwyer, B., \& Owen, D. (2007). Seeking stakeholder-centric sustainability assurance. Journal of Corporate Citizenship, 25(1), 77-94.

O'Dwyer, B., Unerman, J., \& Hession, E. (2005). User needs in sustainability reporting: Perspectives of stakeholders in Ireland. The European Accounting Review, 14(4), 759-787.

Ofosu-Mensah, E. A. (2016). Mining in colonial Ghana: Extractive capitalism and its social benefits in Akyem Abuakwa under Nana Ofori Atta I. Africa Today, 63(1), 22-55.

Özsözgün Çalişkan, A. (2014). How accounting and accountants may contribute in sustainability? Social Responsibility Journal, 10(2), 246-267.

Park, J., \& Brorson, T. (2005). Experiences of and views on third-party assurance of corporate environmental and sustainability reports. Journal of Cleaner Production, 13(10), 1095-1106.

Parker, L. D. (2000). Green strategy costing: Early days. Australian Accounting Review, 10(20), 46-55.

Parker, L. D. 2011. Twenty-one years of social and environmental accountability research: A coming of age. Paper read at Accounting Forum.

Pierce, B., \& O'Dea, T. (2003). Management accounting information and the needs of managers: Perceptions of managers and accountants compared. The British Accounting Review, 35(3), 257-290.

Porter, M. E. (2003). Corporate philanthropy: Taking the high ground. Foundation strategy group, Boston, MA, 1-12.

ROSC. (2014) Report on the Observance of Standards and Codes - Accounting and Auditing (ROSC A\&A), World Bank. Available at https://www.WorldBank. org/ifa/2015/GhanaROSC-A\&A2014.pdf. Accessed 24 Oct 2015.

Sarstedt, M., Ringle, C. M., Smith, D., Reams, R., \& Hair, J. F. (2014). Partial least squares structural equation modeling (PLS-SEM): A useful tool for family business researchers. Journal of Family Business Strategy, 5(1), 105-115.

Scapens, R., \& Jazayeri, M. (2003). ERP systems and management accounting change: Opportunities or impacts? A research note. The European Accounting Review, 12(1), 201-233.

Schaltegger, S., \& Burritt, R. L. (2010). Sustainability accounting for companies: Catchphrase or decision support for business leaders? Journal of World Business, 45(4), 375-384.

Schaltegger, S., \& Wagner, M. (2006). Integrative management of sustainability performance, measurement and reporting. International Journal of Accounting, Auditing and Performance Evaluation, 3(1), 1-19.

Schaltegger, S., \& Zvezdov, D. (2013). In control of sustainability information: Untangling the role of accountants. In Accounting and Control for Sustainability (pp. 265-296). Bingley: Emerald Group Publishing Limited. 
Schaltegger, S., \& Zvezdov, D. (2015). Gatekeepers of sustainability information: Exploring the roles of accountants. Journal of Accounting and Organizational Change, 11(3), 333-361.

Schaltegger, S., Burritt, R., \& Petersen, H. (2003). An introduction to corporate environmental management: Striving for sustainability. Vol. 14. Bingley: Emerald Group Publishing Limited.

Schaltegger, S., Gibassier, D., \& Zvezdov, D. (2013). Is environmental management accounting a discipline? A bibliometric literature review. Meditari Accountancy Research, 21(1), 4-31.

Sisaye, S. (2011a). Ecological systems approaches to sustainability and organizational development: Emerging trends in environmental and social accounting reporting systems. Leadership and Organization Development Journal, 32(4), 379-398.

Sisaye, S. (2011b). The functional-institutional and consequential-conflictual sociological approaches to accounting ethics education: Integrations from sustainability and ecological resources management literature. Managerial Auditing Journal, 26(3), 263-294.

Sisaye, S., \& Birnberg, J. G. (2010). Organizational development and transformational learning approaches in process innovations: A review of the implications to the management accounting literature. Review of Accounting and Finance, 9(4), 337-362.

Starik, M., \& Kanashiro, P. (2013). Toward a theory of sustainability management: Uncovering and integrating the nearly obvious. Organization \& Environment, 26(1), 7-30.

Thoradeniya, P., Lee, J., Tan, R., \& Ferreira, A. (2015). Sustainability reporting and the theory of planned behaviour. Accounting, Auditing \& Accountability Journal, 28(7), 1099-1137.

Vincent, J. R. (2000). Green accounting: from theory to practice. Environment and Development Economics, 5(01), 13-24

Weidman, S. M., Curatola, A. P., \& Linnehan, F. (2010). An experimental investigation of the intentions to accrue and disclose environmental liabilities. In Ethics, Equity, and Regulation (pp. 195-243). Bingley: Emerald Group Publishing Limited.

Wilmshurst, T. D., \& Frost, G. R. (2001). The role of accounting and the accountant in the environmental management system. Business Strategy and the Environment, 10(3), 135-147.

Zvezdov, D., Schaltegger, S., \& Bennett, M. (2010). The increasing involvement of accountants in corporate sustainability management. Journal of the AsiaPacific centre for environmental accountability, 16(4), 20-31.

\section{Submit your manuscript to a SpringerOpen ${ }^{\circ}$ journal and benefit from:}

- Convenient online submission

- Rigorous peer review

- Open access: articles freely available online

High visibility within the field

- Retaining the copyright to your article

Submit your next manuscript at $\boldsymbol{\nabla}$ springeropen.com 